\title{
Ensino Religioso como política pública educacional: um desafio para a Ciência da Religião no Brasil ${ }^{1}$
}

\author{
Waldney de Souza Rodrigues Costa
}

\section{RESUMO}

Há grupos no Brasil propondo a transformação do Ensino Religioso em uma política pública, ou seja, que, tornado um saber escolar que contemple a diversidade religiosa do país, tenha seus conteúdos fixados pelo Estado. Em meio a eles tem-se estabelecido o consenso de que a Ciência da Religião é a área ideal para habilitação de docentes da disciplina e seleção dos conteúdos. Neste ensaio proponho uma reflexão sobre o que entendo ser um desafio que isso coloca para a área, tendo em vista sua configuração atual. Faço uma brevíssima revisão de sua história, da origem europeia à emersão no Brasil, acentuando, a partir da bibliografia selecionada, pontos incômodos que deveriam ser levados em consideração na defesa dessa proposta.

Palavras-chave: Ciências da Religião. Ensino Religioso. Política pública educacional. Religião.

\section{RELIGIOUS EDUCATION AS A EDUCATIONAL PUBLIC POLICY: A CHALLENGE FOR RELIGIOUS STUDIES IN BRAZIL}

\begin{abstract}
There are groups in Brazil proposing to transform religious education into public policy, that is, in addition to being transformed into a school knowledge that contemplates the religious diversity of the country, it must has its contents fixed by the State. In this circuit a consensus has been
\end{abstract}

\footnotetext{
O texto é derivado da aula que tive que apresentar à banca de avaliação do concurso que prestei por ocasião de minha admissão como professor do Departamento de Ciências da Religião da Universidade do Estado do Rio Grande do Norte (UERN), Edital 001/2016. Agradeço imensamente às críticas dos dois pereceristas anônimos da Revista Correlatio que fizeram importantes sugestões para a qualificação do trabalho, embora reconheça que não foi possível atender a todas.
} 
established that Religious Studies is the ideal discipline for qualification of teachers and fixation of contents. In this essay I reflect on which makes this a challenge for this disciplinary field, in view of its current configuration. I make a very brief review of your history, of European origin to the emergence in Brazil. I emphasize, in the selected bibliography, uncomfortable points that should be taken into account in this proposal.

Keywords: Religious Studies. Religious Education. Educational public policy. Religion.

\section{Ensino Religioso como política pública e uma discussão necessária}

Há no Brasil um número de pessoas que, desde o final do século $\mathrm{XX}$, têm defendido uma radical reinterpretação do Ensino Religioso, disciplina que durante muito tempo foi entendida como presença da religião cristã (sobretudo em sua expressão católico romana) no espaço escolar, utilizado para divulgação e fixação de seus preceitos. O grupo defende que ele seja transformado em uma política pública, ou seja, que o Estado brasileiro, assumindo o controle deste componente curricular, trate-o como qualquer outro, definindo diretrizes, parâmetros e currículo; como forma de garantir que a diversidade religiosa presente no país seja contemplada. Grande parte desse grupo tem se reunido no Fórum Nacional Permanente de Ensino Religioso (FONAPER), mas não só.

Tal proposta encontra resistência por uma parcela da Academia (sobretudo pedagogos e sociólogos da educação) que entende que ela afronta a laicidade do Estado (CUNHA, 2016). Não é aqui o melhor espaço para fornecer um panorama desse embate. Antes, assumirei que a forma particular com que os princípios da laicidade se configuram no Brasil não impede que haja algum espaço para ações relacionadas a religião nas políticas públicas educacionais. É algo que me pareceu muito claro quando o Ministério da Educação selecionou como tema da redação do Exame Nacional do Ensino Médio (ENEM) de 2016 os "caminhos para combater a intolerância religiosa". Porém, como não é certo que tal espaço precise se configurar nos termos defendidos pelo Fonaper, convém uma discussão mais aprofundada sobre as implicações desses termos. 
Para o entendimento da questão que aqui quero discutir, é importante ter alguma clareza sobre a distinção entre política pública e saber escolar, bem como suas relações. Muitas são as políticas públicas educacionais, assim como muitos são os saberes que circulam nas escolas e são coisas que não necessariamente coincidem. Porém, quando o Estado define parâmetros ou diretrizes para um ensino e/ou fixa certos conteúdos como obrigatórios, tal intervenção configura uma política pública. Cada saber em si não é uma intervenção política direta, mas o ato de fixar no âmbito estatal quais saberes devem ser trabalhados nas escolas assume esse caráter. É isso que configura a definição do que se deve ensinar no Ensino Religioso numa Base Nacional Comum Curricular (BNCC) $)^{2}$.

Bem é verdade que a relação em jogo é muito complexa. As teorias do currículo, em sua primeira onda surgida no final dos anos 1960, destacavam o currículo escolar como um conjunto de relações de poder em si mesmo, ainda que indiretas, porém, na sua segunda fase iniciada nos anos 1980, ampliaram o contato com teorias do conhecimento e isso teve impacto na concepção do que é ou deveria ser um saber escolar (MOREIRA, 1990). O inglês Michael Young, especialista experiente nessa área e principal expoente dessa transição, em uma entrevista (GALIAN, LOUZANO, 2014), explicou que, se antes a crítica do currículo como política em si implicava na convicção de não haver uma base objetiva para distinguir diferentes tipos de conhecimento trabalhados na escola, num segundo momento constatou-se que existe um tipo de saber gerado em qualquer sociedade e considerado o melhor até então desenvolvido para explicar o mundo e que este é o que deveria ser transmitido pela escola, pois grande parte da população, sobretudo a mais vulnerável, não o obteria por nenhum outro meio, já que é diferente do conhecimento cotidiano. Tal virada ficou conhecida na sociologia da educação como a mudança da ênfase no "currículo dos poderosos" para a defesa do "currículo poderoso" (GALIAN, LOUZANO, 2014). O gatilho foi a constatação de que há saberes que empoderam mais que outros para as possibilidades de intervenção no mundo.

2 Esse documento, previsto pela Lei de Diretrizes e Bases da Educação Nacional (LDB), definirá qual o conteúdo mínimo a ser trabalhado em todas as escolas presentes no Brasil. Foi aprovado em 2017 e tem previsão de revisão a cada cinco anos. 
A questão "pra que servem as escolas?" é central nessa nova teorização e sua resposta só pode ser dada pela diferença entre conhecimentos escolares e não escolares (YOUNG, 2007). Nesse sentido, saberes cotidianos, advindos da experiência, podem ser apropriados pela escola para facilitar o ensino, mas este não é o seu objetivo principal, pois "não há nenhuma utilidade para os alunos em se construir um currículo em torno da sua experiência" (YOUNG, 2007, p. 1297). Para Young, a função da escola é fornecer conceitos aos quais não se tem acesso em casa, pois é isso que empodera e há não garantia de que seja fornecido por outra instituição (GALIAN, LOUZANO, 2014). Sem eles, o currículo torna-se "um bate-papo como o que se tem em casa; e não se precisa da escola para isso" (YOUNG apud GALIAN, LOUZANO, 2014, p. 1120). Mas o grande problema é que a definição de qual é conhecimento que deve ser trabalhado na escola é feito em outro lugar! É aí que o saber escolar revela-se uma questão de política pública.

Políticas públicas são ações intencionais de governos e Estados que buscam definir e compatibilizar objetivos e meios entre atores sociais sujeitos a restrições. Elas se distinguem pela relevância social do alcance de seu conteúdo, diferenciando-se, por exemplo, das políticas de Estado, cujo conteúdo se direciona à própria manutenção e viabilização do exercício do poder. Têm a ver com a decisão que envolve um conjunto de ações em torno de fazer ou não fazer algo deliberadamente a respeito de determinada questão social (HOWLETT; RAMESH; PERL, 2013, p. 7-8). Quando isso é feito em relação à educação, configura-se uma política pública educacional. É o que acontece quando se define o que deve ser ensinado nas escolas através de uma base curricular.

Há muitos desafios a serem enfrentados nos estudos de políticas públicas e eles se farão presentes ao se tratar de religião ou de Ensino Religioso. Arretche (2003) explica que há atualmente uma proliferação de estudos de caso, mas falta um paradigma e uma agenda de pesquisa que independa da agenda política do país. E os estudos estão muito concentrados na formulação de políticas. Faltam análises mais sistemáticas da implementação e da avaliação. E em meio a isso, o papel das ideias e do conhecimento tem sido praticamente ignorado (FARIA, 2003). Como alerta Faria (2003, p. 23), são cruciais para a compreensão da formação da agenda de qualquer política pública. Mas vejo que isso 
é ainda mais grave na política educacional de definição do currículo, pois, nesse caso, a própria intervenção é uma gestão do conhecimento, tendo impacto direto também na implementação e nas possibilidades de avaliação. Ela constitui um verdadeiro encontro entre política pública, saber escolar e campo de conhecimento.

Veja que isso não necessariamente relaciona-se com o alcance de um bem maior através do conhecimento, algo muito defendido pelos grupos que propõem a transformação do Ensino Religioso em uma política pública. Exemplifico com a posição da professora Elisa Rodrigues (2013, p. 226) ao propor que se faça "do conhecimento da religião um instrumento para a cidadania ativa", bem como o de sua orientanda ao trabalhar o Programa Institucional de Bolsas de Iniciação à Docência (PIBID) de Ensino Religioso da Coordenação de Aperfeiçoamento de Pessoal de Nível Superior (CAPES) como uma "política pública de combate à intolerância religiosa" (OLIVEIRA, 2017). Por mais nobre que sejam esses objetivos, o posicionamento de conhecer para fazer, combater, criar ou impedir algo tem sido muito criticado pelas mais recentes teorias da educação, por conta da constatação de que o objetivo primeiro do ensino escolar é conhecer para melhor conhecer. Nada contra o fomento à cidadania ou o combate à intolerância, mas isso precisa ser visto como papel secundário, assim como o combate ao bullying ou à gravidez na adolescência, a mudança dos hábitos alimentares e esportivos das crianças e uma série de outros problemas sociais que estão sendo lançados no âmbito escolar. Nóvoa (2007, p. 6) vê nisso um "transbordamento da escola", pois gera um "excesso de missões" que precisa ser combatido porque cria um excesso de dispersão, especialmente entre os professores. Essas missões são muito importantes, mas a escola não pode fazer tudo e deve condicioná-las ao que deve ser prioritário para os docentes (NÓVOA, 2007, p. 6). A prioridade é o que a escola foi criada para garantir que aconteça. O que, para Nóvoa (2007) é a aprendizagem dos alunos e, nos termos de Young (2007), é o conhecimento para além da experiência cotidiana.

Nesse sentido, se a seleção e definição desse conhecimento não é feita apenas pelo próprio professor ou pela própria escola ${ }^{3}$, mas

Esta é a posição adotada no Brasil por uma parcela de docentes radicalmente contrária à criação de qualquer tipo base curricular comum (CUNHA, 2016). 
por órgãos estatais, tem-se que, independente do bem que se queira alcançar com o Ensino Religioso, o próprio ato de definir via Estado quais são os seus conteúdos obrigatórios já configura uma política pública em si mesmo. E isso não o faz menos importante que as missões secundárias, pois está diretamente relacionado com a identidade profissional do professor, a clareza dos alunos sobre o que estão fazendo na escola e, o que inspirado em Young considero mais importante, a possibilidade de transpor a experiência cotidiana (GALIAN, LOUZANO, 2014). A consequência é que propor que o Estado defina quais os conteúdos obrigatórios do Ensino Religioso equivale-se a propor não apenas que esse componente seja um saber escolar mais que religioso, mas também a propor que ele se torne uma política pública. E uma realidade que carece de maior reflexão é a de que, para que isso aconteça, o Ensino Religioso precisa se tornar, como os demais componentes curriculares, a aplicação de um ramo das ciências. É isso que interessa mais imediatamente a este artigo. Então, o seu título, Ensino Religioso como política pública educacional, pode até revelar-se um pouco impreciso num primeiro momento, mas não se condicioná-lo ao seu subtítulo. Interessa-me aprofundar, não a proposição em si mesma, mas as suas implicações desafiadoras e não tão óbvias para o campo disciplinar que ela demanda, pois é inerente que a possível transformação do Ensino Religioso em um componente curricular que recontextualiza uma área acadêmica no âmbito escolar será influenciada pelo estado da arte da área em questão.

Sendo assim, este é um ensaio sobre a configuração atual do campo de conhecimento voltado para a reflexão e a pesquisa sobre religião no Brasil. Faço a opção por sua grafia como Ciência da Religião para facilitar a leitura, mas me refiro à complexa área também chamada de Ciências da Religião (como o é na Universidade do Estado do Rio Grande do Norte e nas universidades católicas em geral), de Ciências das Religiões (como o é na Universidade Federal da Paraíba), ou, ainda, de Ciência das Religiões (como o é na Universidade Lusófona, em Portugal). É comum o uso do recurso gráfico Ciência(s) da(s) Religião(ões), 
fixado desde Teixeira (2001), mas em prol da estética deste texto optarei pelo duplo singular ${ }^{4}$.

Se há discordâncias quanto à própria nomenclatura da área, o que dizer de sua aplicação? Esse é o aspecto sobre o qual quero pensar neste texto. Tenho em vista o fato de que, no Brasil, as pessoas que defendem que o Ensino Religioso seja transformado numa política pública de educação estão cada vez mais concordando que, para que isso de fato aconteça, é nesse campo que docentes responsáveis por esse ensino deveriam se habilitar e não em Ciências Sociais, História ou mesmo a Teologia. Meu argumento é que isso imprime um desafio específico à Ciência da Religião feita por aqui.

Para apresenta-lo, selecionei alguns aspectos da bibliografia disponível e algumas informações que obtive trabalhando nesta área, tendo em vista acentuar, na história desse campo de conhecimento, desde a sua origem em alguns países europeus até sua aplicação ao Ensino Religioso no Brasil, como o problema se estabeleceu. Ao final, até indico um caminho possível, mas é mais relevante colocar a questão em destaque. Mais do que ampliar os debates sobre ela, penso que cada cientista da religião que toma consciência de sua pertinência, tem mais clareza de seu lugar na área. E, também, que isso afeta diretamente a possibilidade de definição política de currículo, diretrizes e parâmetros que tomem a Ciência da Religião como base. O que comento ao final.

Devo adiantar que esse ensaio é fruto de um debate mais amplo sobre a configuração da Ciência da Religião no Brasil, no qual se inserem muitos profissionais do campo, especialmente docentes e discentes com passagem pelo programa de Pós-Graduação em Ciência da Religião da Universidade Federal de Juiz de Fora, o primeiro a se estabelecer numa universidade pública (PIEPER, 2017; SILVEIRA, MORAES JÚNIOR, 2017; SILVEIRA, COSTA, 2015; COSTA, 2014; GROSS, 2012; PORTELA, HUFF JÚNIOR, 2012; CAMURÇA, 2008; TEIXEIRA, 2001). Diante dessa grande discussão, muitos argumentos apresentados não

4 Cabe a ressalva de que não se trata de uma questão de preferência pessoal. Por mim, chamaria a área de Religiologia, o que resolveria o problema do singular ou plural. Mas como esse nome têm quase nenhuma visibilidade no Brasil e sua discussão seria uma digressão desnecessária no debate proposto, julguei melhor trabalhar com um termo mais conhecido. Como a argumentação é feita em torno de um componente curricular e uma área de conhecimento, o singular acaba deixando o texto mais fluido. 
ganharão aqui a profundidade devida. Quem quiser se inteirar, pode consultar a bibliografia que será citada ao longo do texto.

Tendo em vista o objetivo geral que é apresentar qual é o principal desafio que a proposta do Ensino Religioso como política pública educacional coloca para a Ciência da Religião no Brasil, a discussão foi dividida em duas partes. Na primeira tenho em vista apresentar a constituição da área e como seu desenvolvimento conformou uma questão específica. O objetivo da segunda é informar como isso se configura no Brasil, tendo em vista a situação atual do Ensino Religioso. Termino indicando como tenho lidado com isso e enfatizando a pertinência do problema.

\section{Ciência da Religião e sua possibilidade de sistematização}

Quase em todo lugar em que a Ciência da Religião se estabeleceu, surgiu das aspirações de liberdade de pensamento sobre âmbito (há quem prefira fenômeno) em torno do qual se organiza. Liberdade, sobretudo em relação à hierarquia eclesiástica cristã. Por isso, muitas vezes é tida como filha emancipada da Teologia. Nessa busca, a religião enquanto tema de reflexão sempre foi alvo de controvérsias e mal-entendidos; porém, um pensamento específico parece ter sido essencial para o estabelecimento da área. Trata-se da ideia cuja sistematização teve uma importante contribuição do teólogo e filósofo polonês Friedrich Schleiermacher (1768-1834) na virada do século XVIII para o XIX, principalmente em seus textos Sobre a Religião (SCHLEIERMACHER, 1990). A de que o cristianismo era apenas uma espécie de um gênero muito maior.

A partir disso, a reflexão outrora centrada no cristianismo e a serviço de suas instituições teve que conviver cada vez mais com outras expressões humanas agora percebidas como religiões. E começou a ser praticada em outro ambiente institucional, dando origem a um saber diferenciado da reflexão teológica vigente até então. Passos e Usarski (2013) contam que no final do século XIX, embora não houvesse acordo a respeito da nomeação desse campo (Ciência da Religião, Religião Comparada, História das Religiões...), já existia certa consciência corporativa de quem nele trabalhava, de modo que surgiram as primeiras 
cátedras na Suíça, na França, na Bélgica e na Holanda; e, no início do século seguinte, na Inglaterra, na Alemanha e na Itália. Era a afirmação a área na Europa ocidental.

Passos e Usarski (2013) também comentam que nesse período de formação estabeleceram-se pelo menos três consensos. Um é de que deveria haver entre os profissionais da área uma espécie de abstinência de julgamento a respeito da validade de cada expressão religiosa. $\mathrm{O}$ outro é de que o novo campo teria vocação interdisciplinar (embora ainda não fosse pensada com esse conceito), devendo se valer das contribuições das demais Ciências Humanas, tais como a Sociologia, a História e a Antropologia. Por fim, o trabalho seria realizado em duas frentes. Uma de viés contextual, analisando cada religião em um tempo e espaço específico e outra em caráter sistemático, buscando comparar religiões e desvendar as aproximações entre elas.

No entanto, à medida que o campo se desenvolveu esses consensos foram desfeitos. $\mathrm{O}$ avanço do trabalho em outros campos disciplinares gerou duras críticas ao que seus profissionais entenderam como religião, tal como aconteceu na sociologia marxista e na psicologia freudiana (ALVES, 1984), o que reverberou na área. Paralelo a isso, parte dos seus profissionais buscou na Fenomenologia religiosa fundamento para a sistematização do saber. Em alguns casos, isso aconteceu exatamente em busca de uma abordagem mais empática com as experiências pesquisadas em contraposição ao olhar das outras Ciências Humanas, tido como reducionista. Como resultado, até hoje especialistas se dividem entre quem pensa a área como uma disciplina em particular e quem prefere toma-la como campo interdisciplinar. $\mathrm{O}$ desacordo quanto à forma de nomeá-la, se no plural ou singular, passa por essas divergências (CAMURÇA, 2008). Decorre disso que, embora reflexões sobre expressões religiosas em particular tenham se mantido, a forma de amarra-las em um projeto maior, comparado ou sistemático, tornou-se controversa.

Em vários casos os autores que pretenderam um trabalho sistemático presumiram uma essência comum às tradições tidas como paralelas ou equivalentes ao Cristianismo e essa é a origem da controvérsia. É por isso que propostas significativamente diferentes como as de Rudolf Otto (2007), Joachim Wach (1990) e Mircea Eliade (2008, 2001) são tomadas em conjunto pelos seus detratores e acusadas de essencialismo 
acrítico, como o faz Gasbarro (2013). Para além do etnocentrismo do qual as propostas de sistematização nem sempre conseguiram escapar, muitas vezes pressupondo o cristianismo como uma forma mais elevada de religião, a existência de uma essência comum a partir da qual fosse possível a comparação foi duramente questionada.

São variados os motivos do questionamento. Destaco os advindos do estudo de sociedades não ocidentais. Como explica Hock (2010), em muitos grupos humanos os antropólogos não encontraram a religião como uma esfera específica. São culturas em que tudo parecia ser religião, deixando a análise confusa a respeito da validade de aplicação da categoria (HOCK, 2010, p. 19). Um sintoma atual dessa realidade é que comunidades indígenas no Brasil não reconhecem suas tradições na categoria religião quando entrevistadas por ocasião dos recenciamentos, muitas vezes se identificando como "sem religião" (PISSOLATO, 2013). Mas o problema é mais complexo. Estudos demonstraram que mesmo as sociedades que reconhecem a categoria, tais como a China ou o Japão, possuem noções muito distintas daquelas inerentes ao cristianismo. Termos como din, dharma e tao não parecem ter em seus contextos exatamente o mesmo sentido do que era tido como primordial no âmbito cristão (HOCK, 2010, p. 20). Como adverte Gasbarro (2013, p. 77), alguns aspectos aparentemente essenciais à religião, como a oposição entre sagrado e profano, cada vez mais se revelaram específicos do Ocidente.

As complicações tendem a se agravar com o movimento intelectual que tem sido conhecido como pós-colonialismo. Wirth (2013) explica que especialistas que se alinham com os princípios dessa corrente de pensamento têm questionado a transformação da religião em objeto de pesquisa justamente quando ela deixa de ser legitimadora do projeto de colonização de povos. Nesse esforço, estudos do próprio cristianismo têm demonstrado que ele adquiriu sentidos muito diferentes ao longo do tempo. Asad (2010) demonstra isso comparando-o na Europa Medieval e na Modernidade.

O resultado é que a tarefa de sistematização está cada vez mais sob suspeita e com ela a possibilidade de estabelecer um paradigma para a Ciência da Religião, uma vez que a própria ideia de religião como categoria universal é questionada. Com isso, o campo entrou em 
um processo de autocrítica e revisão em todo o mundo. Mas isso tem efeitos específicos aqui no Brasil.

\section{Ciência da Religião no Brasil e o Ensino Religioso}

Como não somos alemães, nem holandeses, recebemos a crítica da disciplina antes de seu devido processo de institucionalização. A autonomia da reflexão sobre religião na grade de conhecimento da Capes só foi anunciada em agosto de 2016, e fixada em 2017, ainda assim em conjunto com a Teologia ${ }^{5}$. A criação de uma área específica como "Ciências da Religião e Teologia" é um ganho coorporativo, mas ainda expressa as tensões do campo. Como distinguir a tarefa dos cientistas da religião da dos teólogos?

A institucionalidade também não é plena nas associações científicas e profissionais. O único coletivo voltado especificamente para a área de que tenho notícia é a ACREPA, a Associação de Cientistas da Religião do Estado do Pará que, como visto, tem sua atuação limitada a uma região do país. As associações que abrigam cientistas da religião a nível nacional o fazem ao lado dos teólogos, como a Sociedade de Teologia e Ciências da Religião (SOTER) e a Associação de Pesquisa e Pós-graduação em Teologia e Ciências da Religião (ANPTECRE) ou ao lado de profissionais das mais diferentes áreas, como é o caso da Associação Brasileira de História das Religiões (ABHR). Embora tais entidades tenham uma grande contribuição para o campo, falta um ambiente que confira uma identidade específica para o profissional que dele egressa.

Não levei em consideração a Rede de Licenciaturas em Ensino Religioso (RELER) por ser ela um braço do Fonaper, o qual não agrega apenas cientistas da religião, mas quaisquer profissionais identificados, e somente se identificados, com a sua proposta de Ensino Religioso em todos os níveis de escolaridade como forma de garantir ao aluno a educação de sua "busca do transcendente", algo que não é consenso

\footnotetext{
$5 \quad$ Notícia disponível em: < http://www.anptecre.org.br/index.php?pagina=grupo noticia\&tela=10\&vw=259 $>$. Acesso em 24 mar. 2017.

6 Veja a Carta de Princípios, a qual se precisa dar anuência para filiar-se, disponível em: $<$ http://www.fonaper.com.br/carta-principios.php $>$. Acesso em 16 dez. 2017.
} 
na própria Ciência da Religião e não apenas na Academia em geral. Falarei mais sobre isso a seguir.

Essa baixa institucionalidade interfere nos processos de troca de informações e formulação de propostas de articulação, bem como no compartilhamento das existentes. Os próprios profissionais acabam não se vendo como cientistas da religião, mas como teólogos, sociólogos, filósofos, antropólogos... O que não era um problema no processo de emersão do campo no país. Como surgiu como pós-graduação, os alunos que nele ingressavam tinham a formação inicial em outras disciplinas e o corpo docente, salvo raros casos de formação estrangeira, também havia realizado toda a formação em outro campo. Mas isso faz com que os egressos da área tenham baixo reconhecimento entre as outras e, com eles, ela mesma. É verdade que isso afeta principalmente a pós-graduação, mas é nela que, por definição, estão os estudos mais avançados. Isso não quer dizer que não existam estudos de ponta feitos por graduandos, mas a regra socialmente reconhecida é a de que a vanguarda está na pós.

E como pessoas que se pós-graduaram em Ciência da Religião têm trabalhado num cenário como este? Uma possibilidade é simplesmente ignorar esse ambiente hostil. Especializar em uma disciplina de maior aptidão, que pode ser a Filosofia, a Teologia, a Sociologia ou qualquer outra área das Humanidades e aplica-la à religião. O cenário favorece essa opção. Ao escolher uma disciplina é possível filiar-se a uma conceituação sem necessariamente enfrentar suas contradições face às outras. Assim, pode-se assumir premissas essencialistas fenomenológicas sem levar em conta a desessencialização operada pelas Ciências Sociais (HUFF JÚNIOR, 2015); ou tomar a religião como sistema de sentido ou "preocupação última" sem considerar que algumas experiências comumente tidas como religiosas são extremamente desnorteadoras e até mesmo subversivas (como as de conversão) (PIEPER, 2015b); ou ainda tomar religião pela sua função social desconsiderando que a diversidade humana não se explica apenas pelas funcionalidades (RODRIGUES, 2015). O campo da Ciência da Religião seria apenas um ambiente em que os diversos profissionais se encontram, cada um com sua perspectiva, para discutir sobre o que pensam ser religião. 
É claro que nenhuma perspectiva será completa e há sim, necessidade de especialização. Só que o problema em torno da aplicação demanda maior coesão epistemológica do campo, algo que não pode ser alcançado nesse caminho que estamos seguindo e a possibilidade de tornar o Ensino Religioso uma política pública educacional deixa isso muito evidente. Idealizado na Constituição de 1988 como componente curricular das escolas públicas, de matrícula facultativa e de caráter "não confessional", tem sido reforçado por uma série de outros dispositivos legais que buscam transformar religião em um saber escolar, não sem conviver ambiguamente com outros dispositivos contrários a isso ${ }^{7}$. Partindo de um princípio de laicidade, mas reconhecendo a relevância do conhecimento sobre religião, ações políticas, encampadas principalmente pelo Fonaper, buscam um modelo adequado à diversidade religiosa do país. Uma ideia que parece aglutinar as forças é a de que o Estado não pode interferir nas opções religiosas de seus cidadãos, mas deve fomentar práticas e desestimular outras. Fomentar as que contribuam para o bem estar social e desestimular as marcadas pela intolerância e pela violência, inclusive simbólica.

Mas não se pode perder de vista que, até pouco tempo (ainda hoje?), o Ensino Religioso era visto como aquele dedicado à transmissão dos preceitos do cristianismo (quase sempre em sua versão católica) ou da cooperação ecumênica entre cristãos. É com o objetivo de mudar esse perfil, de modo que abrisse maior espaço para as expressões religiosas não cristãs, que surgiu a questão a respeito de qual seria a habilitação ideal para o seu profissional.

Após anos de debate, tem-se estabelecido entre profissionais da educação que defendem a transformação do Ensino Religioso em um saber escolar como qualquer outro, um razoável consenso de que é a Ciência da Religião a formação mais adequada para o professor responsável por esse componente (JUNQUEIRA, 2015b). É nesse processo que surgiram as graduações na modalidade de licenciatura. Hoje existem pelo menos doze no país, mas apenas quatro estão fixadas em instituições que possuem pós-graduação stritu sensu (Mestrado e/ou Doutorado). São a UFJF, a UFPB, a UFS (Universidade Federal do Sergipe) e a UEPA

Há uma descrição desses dispositivos e suas tensões em Junqueira (2015a). 
(Universidade do Estado do Pará). Três delas de criação muito recente (surgiram respectivamente em 2012, 2009, 2013 e 2003).

Ciência da Religião como área de formação dos docentes em Ensino Religioso pode parecer uma obviedade, mas não é. Além de não ser uma postura hoje adotada na maior parte das unidades federativas do Brasil, não parece ser muito comum na experiência internacional. Tal concepção só se consolida em 2006 num evento promovido pelo Fonaper (PIEPER, 2017, p. 136). Sendo assim, a criação de graduações em Ciência da Religião na modalidade de licenciatura dependeu muito da atuação deste fórum que há mais de vinte anos reúne pessoas em torno da discussão do Ensino Religioso. A meu ver, ele não pode ser pensado como associação acadêmica ou científica por não capitanear as reflexões que se contrapõem ao seu posicionamento (bem limitado, por sinal) a respeito desse ensino, distanciando-se da pluralidade necessária à profissionalização de qualquer ciência. O que também não quer dizer que ele possa ser considerado uma instituição religiosa cristã, como o acusa Cunha (2016). Isso é um grande equívoco se colocado à luz dos muitos embates entre o fórum e instituições religiosas católicas, sobretudo decorrentes da sua luta pelo fim daquilo que chama de ensino "confessional". Ele assemelha-se mais a um sindicato, composto por diferentes profissionais da educação que se identificam com o tipo de Ensino Religioso que o fórum defende. Levando em conta que a maioria dos que nele se reúnem tiram o seu sustento desse ensino, não seria forçoso pensa-lo como o sindicato dos professores de educação religiosa.

As propostas do Fonaper são sintomáticas dos desencontros entre a graduação e a pós. Nos seus documentos e nos textos publicados com sua chancela é pressuposta uma coerência em torno da religião que não existe na pós-graduação. Fala-se em fenômeno religioso, experiência religiosa e, não raras vezes, defende-se que o método da Ciência da Religião é o fenomenológico ${ }^{8}$. Nada mais distante da realidade deste campo no país ao nível dos estudos pós-graduados. Porém, isso expressa uma pendência específica. Procura-se um artifício para trabalhar com alunas e alunos as muitas formas de religião (ou muitas religiões, como queira) em um horizonte comum, permitindo não apenas apresentar

Também em Junqueira (2015a) tem-se um panorama dessa situação. 
as diversas expressões religiosas à nossa volta, mas também discutir relações inter-religiosas e entre religiosos e não religiosos, no sentido de conscientizar dos direitos e deveres em matéria de religião. Não foi essa a demanda da redação do ENEM de 2016? Entretanto, essa espécie de divórcio entre a graduação e a pós faz com que o horizonte comum necessário não seja teorizado, pois, na primeira é pressuposto e, na segunda, ignorado. É verdade que estamos cada vez mais distantes de assumir um método único (SILVEIRA, MANOEL MORAES, 2017); mas a afirmação corriqueira de que o campo da Ciência da Religião é pluriparadgmático e plurimetódico não responde ao desafio, pois, de modo geral, toda ciência, sobretudo as Humanas, possuem esse perfil.

A meu ver, o caso do Ensino Religioso demonstra a necessidade de firmar o caráter disciplinar desse campo no Brasil. O problema é que temos condicionado a possibilidade de uma disciplina a uma metodologia básica e cada vez mais fica claro que nenhum método em especial será capaz de unificar a área (SILVEIRA, MANOEL MORAES, 2017). Isso inclui o método fenomenológico por conta das críticas que enumerei acima. Já pensou no quão difícil, por exemplo, é ajudar um aluno a compreender o que há de religioso em coisas como o estado islâmico, a teologia da libertação, os deputados evangélicos ou as religiões midiáticas como o kopismo ${ }^{9}$, pressupondo a clivagem entre sagrado e profano como a essência das religiões, como queria Eliade (2000)? Se esse autor visse como a religião tem se configurado atualmente talvez repensasse essa abordagem.

Não estou convencido de que para afirmar uma disciplina seja necessário um método próprio. A Antropologia, por exemplo, não se confunde com a etnografia. Primeiro porque esse método se revelou tão eficaz como forma de produzir conhecimento que tem sido empregado em diferentes campos disciplinares, tais como as Ciências do Esporte (STIGGER, 2002), a Educação (GOMES, 2010), os Estudos Organizacionais (FANTINEL, 2012) e a própria Ciência da Religião (COSTA, 2015). Depois por que há antropólogos que não fazem etnografias. Essa não era a principal ferramenta de fundadores da disciplina, como Marcel Mauss. Além disso, profissionais do campo antropológico têm

Trata-se de uma religião que vive exclusivamente na internet. Mais informações em Silveira e Avellar (2014). 
descoberto que há outras formas de abordar a diversidade humana, por exemplo, comparando a mesma sociedade em diferentes períodos. É assim que trabalha o saudita Talal Asad.

Perceba que, embora etnografia e antropologia não se confundam, o método etnográfico contribui para estruturar um campo disciplinar. Nem sempre foi assim. Em tempos anteriores ele era identificado muito mais pelo seu objeto: as sociedades de pequena escala pouco afetadas pelos processos da Modernidade. Quando a Antropologia se voltou para outros tipos de sociedade, modernizadas e de maior escala, o trabalho de campo acabou assumindo um papel mais elementar. Ele adquiriu força de paradigma. Embora não possua todo o caráter paradigmático no sentido kuhniano, é um artifício que gera identidade na área. Nela, mesmo quem não trabalha com etnografia, hoje precisa se posicionar a respeito. Como o faz Asad (2003, p. 17), já citado.

Diante do problema exposto, penso que se faz necessário estabelecer algum artifício semelhante no campo da Ciência da Religião. Isso ajudaria não apenas a organizar os debates, mas também a articular as reflexões e pesquisas mais recentes da pós-graduação com as demandas das graduações, sobretudo as licenciaturas. Esse me parece ser o maior desafio que o Ensino Religioso, se transformado em uma política pública, coloca para a Ciência da Religião no Brasil. Criar algo que possa articular as reflexões e pesquisas pós-graduadas que seguem tradições teóricas tão variadas de modo que os principais achados possam passar por uma elaboração didática para os cursos de licenciatura em Ensino Religioso ou graduação em Ciência da Religião. A política pública está exatamente em definir quais devem ser considerados "principais". Não é hoje o currículo um dos grandes desafios do Ensino Religioso? Não é essa a grande polêmica em torno da BNCC? (CUNHA, 2016).

A implicação mais basilar do que foi discutido é que, se for admitida a definição política do currículo do Ensino Religioso, isso não pode ficar apenas nas mãos dos seus professores, pois, como exemplifica Young (GALIAN, LOUZANO 2014) com o caso das definições curriculares na África, eles não tiveram treinamento para isso. Deveriam ser convocados à elaboração especialistas em teoria do currículo, assim como profissionais dos estudos pós-graduados em Ciência da Religião, já que, não é demais insistir, por definição, são os que mais avança- 
ram em teoria da religião. A questão primordial do Ensino Religioso como política pública é descobrir, em meio à miríade de conhecimentos disponíveis sobre religião, quais são aqueles que mais importam, pois a escola não dá conta de fornecer todos e nem tem essa função. Se é preciso responder quais são o que mais empoderam para a intervenção no mundo, não é demais assumir que quem mais avançou na pesquisa de base, embora não possa ter exclusividade, tenha um papel relevante nessa definição e nas eventuais revisões que acontecerão ao longo do tempo. O desafio é que a falta de um critério unificador para a área tem impacto direto na viabilidade de critérios para distinguir os diferentes tipos de saber que nela circulam. Huff Júnior e Portella (2012) têm razão quando evocam a necessidade de consensos mínimos! Profissionais da educação atuantes no Ensino Religioso e nas graduações em Ciência da Religião não deveriam ignorar os achados da pós, mas sem um mínimo de consenso ela pouco pode ajudar...

\section{Um horizonte ainda inconcluso}

Como dito no início, essa reflexão propõe lançar luz num problema, não resolvê-lo. A meu ver, ao se preocupar com a articulação da área, em nível epistemológico e institucional, cientistas da religião podem contribuir para atender melhor as demandas educacionais. Logo, não deveria ser uma preocupação apenas de quem se encarrega de pesquisar a educação religiosa, mas ficar de fundo no trabalho de qualquer pesquisa realizada no campo. Sua coesão é nosso grande desafio. Não conseguimos nos unir nem mesmo em torno do seu nome! Há um grande caminho ainda a ser trilhado.

A despeito desse quadro complexo que aqui só pude levantar alguns poucos aspectos julgados elementares, preciso alertar a quem tenha se admirado da forma como o campo se encontra que propostas têm sido formuladas. Para não terminar o texto de forma desalentada, cito como exemplo a forma como tenho trabalhado, ao considerar oportuna aquela apresentada por Camurça (2008). Para ele, que há mais de vinte anos atua em pós-graduações de Ciência da Religião e de Ciências Sociais, o que dá a cientistas da religião um senso de unidade não é um método comum, nem um objeto, mas um "espírito de época" que 
seria "o horizonte da Modernidade e sua relação com a religião" (CAMURÇA, 2008, p. 56).

Em minhas pesquisas tenho feito o exercício de dar a este "horizonte da Modernidade" força de paradigma. Isso significa tomar essa ideia como pano de fundo de todas as questões que são abordadas, o que faz com que eu trate religião, antes de qualquer coisa, como um conceito. Uma forma discursiva moderna. Seu uso generalizado é mais recente do que geralmente estamos dispostos a admitir (PIEPER, 2015a). Se religião é conceito, a discussão sobre o plural se esvai, por que conceitos nada mais são do que mapas para a realidade, nunca se equivalendo a ela (PIEPER, 2015a). O que também nos liberta da pressuposição de que religião é algo inerente ao ser humano, posicionamento que julgo extremamente contraproducente. Pensemos, por exemplo, nas quase 110 mil pessoas entre 0 e 14 anos que declararam ou foram declarados ateus e agnósticos por ocasião do Censo de 2010 (dados do IBGE). Trabalhar religião como algo inerente ao humano equivale a insinuar que esses milhares de crianças e adolescentes não são humanos completos. É assim que se quer um Ensino Religioso que respeite a diversidade brasileira!?

Se, pelo contrário, religião é tomada como conceito, a questão sobre se é algo inerente ao humano pode ficar em aberto. Assim, posso reler abordagens ditas fenomenológicas, do tido de Eliade, como aquelas que representam as primeiras percepções de que as muitas coisas que percebemos como religiões guardam algo em comum. Mas esse algo não é uma essência, mas um problema com a modernidade. Embora tais abordagens não tenham se constituído nessa direção e, por isso não podem ser tomadas cegamente; elas podem contribuir.

Otto (2000), por exemplo, defendeu que a essência da religião seria o numinoso, uma experiência de completa alteridade que harmoniza atração, fascínio e temor, podendo gerar o que chamou de "sentimento de criatura". No quadro atual, não é razoável pressupor que o sentimento indicado por Otto seja algo da essência da humanidade, nem que seja inerente a tudo o que reconhecemos genericamente como religião. Mas não é preciso trabalhar com tais pressupostos para aceitar que a crença gere um tipo específico de sentimento, o qual foi problematizado com a modernidade, não sem contradições. É possível inclusive considerar que 
esse sentimento tanto esteja ausente em algumas expressões tidas como religiosas, quanto presente em experiências que não são percebidas como tal. Sabemos muito pouco sobre os motivos de cosmologias com aspectos utópicos tão semelhantes como o marxismo e o cristianismo serem lidas em chaves distintas, uma como ideologia e a outra como religião (ALVES, 1984, p. 74). Nisso o horizonte da modernidade pode ajudar. Isso, é claro, se concordaremos que é com ela que surgem as condições para a intensificação do contato entre povos cristãos e não cristãos e da reflexão sobre isso. Intensificação essa que demandou que a palavra religião, até então pouco utilizada e em sentido bem diferente (PIEPER, 2015b), fosse transformada num conceito que cristalizasse a ideia de que o cristianismo é um tipo de algo muito maior. Não é essa ideia, sistematizada por Schleiermacher, que perpassa toda uma tradição, passando por Otto, Eliade e chegando até Paul Tillich?

Como foi dito, e insisto, esse é só um pequenino exemplo diante da gama de questões complexas que estão emaranhadas. Elas não aceitam soluções fáceis. Mesmo a que tenho adotado é, ainda, um exercício. Esse texto só tem a pretensão de apontar o desafio maior. Se o leitor ficou mais curioso a respeito de como aprimorar as articulações da Ciência da Religião e se fez algumas perguntas a respeito de seu papel na possível transformação do Ensino Religioso em uma política pública educacional, ele terá cumprido o seu objetivo.

\section{Referências}

ALVES, Rubem. O suspiro dos oprimidos. São Paulo: Paulinas, 1984.

ASAD, Talal. A construção da religião como uma categoria antropológica. Cadernos de Campo, São Paulo, v. 19, n. 19, p. 263-284, 2010.

. Formations of the secular: Chrstianity, Islam, Modernity. Stanford, California (EUA): Stanford University Press, 2003.

CAMURÇA, Marcelo. Ciências Sociais e Ciências da Religião: polêmicas e interlocuções. São Paulo: Paulinas, 2008.

COSTA, Waldney. "Tem crente no pedaço": um estudo sobre religião e lazer entre jovens evangélicos. 2015. 267 f. Dissertação 
(Mestrado em Ciência da Religião) - Programa de Pós-Graduação em Ciência da Religião, Universidade Federal de Juiz de Fora, Juiz de Fora, 2015.

. Por uma antropologia das crenças dos pesquisadores de crenças: a produção do conhecimento acadêmico sobre religião no Brasil. Paralellus, Recife, v. 5, n. 9, p. 79-92, jan./jun. 2014.

CUNHA, Luiz Antônio. A entronização do Ensino Religioso na base curricular comum. Educação e Sociedade, Campinas (SP), v. 37, n. 134, p. 266-284, jan./mar. 2016.

ELIADE, Mircea. Tratado de história das religiões. 3. ed. São Paulo: Martins Fontes, 2008.

. O sagrado e o profano: a essência das religiões. São Paulo: Martins Fontes, 2001.

FANTINEL, Letícia. Os significados dos espaços e as sociabilidades organizacionais: estudo de um café em Salvador. 2012. 216 f. Tese (Doutorado em Administração) - núcleo de Pós-Graduação em Administração, Universidade Federal da Bahia, Salvador, 2012.

FARIA, Carlos. Idéias, conhecimento e políticas públicas: um inventário sucinto das principais vertentes analíticas recentes. Revista Brasileira de Ciências Sociais, São Paulo, v. 18, n. 51, 2003, p. 21-30.

GALIAN, Cláudia; LOUZANO, Paula. Michael Young e o campo do currículo: da ênfase no "conhecimento dos poderosos" à defesa do "conhecimento poderoso"; Entrevista. Educação e Pesquisa, São Paulo, v. 40, n. 4, p. 11091124, out./dez. 2014.

GASBARRO, Nicola. Fenomenologia da religião. In: PASSOS, João Décio; USARSKI, Frank (Orgs.). Compêndio de Ciência da Religião. São Paulo: Paulus/Paulinas, 2013. v. 1, p. 75-99.

GOMES, Elias. Ensaios etnográficos sobre a socialização da juventude para a sexualidade e a fé: "vem, você vai gostar!". 2010. 186 f. Dissertação (Mestrado em Educação) - Faculdade de Educação, Universidade de São Paulo, São Paulo, 2010.

GROSS, Eduardo. A Ciência da Religião no Brasil: teses sobre a sua constituição e seu desafio. In: OLIVEIRA, Kathlen et al (orgs.). Religião, política, poder e cultura na América Latina. São Leopoldo: EST, 2012. p. 13-26.

HOCK, Klaus. Introdução à Ciência da Religião. São Paulo: Edições Loyola, 2010. 
HOWLETT, Michael; RAMESH, M.; PERL, Anthony. Política pública, seus ciclos e subsistemas: uma abordagem integradora. Rio de Janeiro: Elsevier, 2013.

HUFF JÚNIOR, Arnaldo. Ciência da Religião, teoria social e desessencialização. In: SILVEIRA, Emerson; COSTA, Waldney (Orgs.). A polissemia do sagrado: os desafios da pesquisa sobre religião no Brasil. São Paulo: Fonte Editorial, 2015. p. 85-105.

; PORTELLA, Rodrigo. Ciência da religião, teoria social e desessencialização. Numen, Juiz de Fora, v. 15, n. 2, p. 431-454, jul./dez. 2012.

JUNQUEIRA, Sérgio (Org.). Ensino Religioso no Brasil. Florianópolis: Insular, 2015a.

. Uma ciência de referência: uma conquista para o Ensino Religioso. REVER - Revista de Estudos da Religião, São Paulo, ano 15, n. 3, p. 1025, jul./dez. 2015 b.

MOREIRA, Antônio. Sociologia do currículo: origens, desenvolvimento e contribuições. Em aberto, Brasília, ano 9, n. 46, p. 72-83, abr./jun. 1990.

NÓVOA, António. Desafios do trabalho do professor no mundo contemporâneo. São Paulo: SINPRO-SP, 2007.

OLIVEIRA, Tania. O PIBID de Ensino religioso como política pública de combate à intolerância religiosa. 2017. 156 f. Dissertação (Mestrado em Ciência da Religião) - Programa de Pós-Graduação em Ciência da Religião, Universidade Federal de Juiz de Fora, Juiz de Fora, 2017.

OTTO, Rudolf. O sagrado. São Leopoldo: EST/Sinodal; Petrópolis, RJ: Vozes, 2007.

PASSOS, João Décio; USARSKI, Frank. Apresentação geral. In:

(Orgs.). Compêndio de Ciência da Religião. v. 1. São Paulo: Paulus/Paulinas, 2013. p. 17-29.

PIEPER, Frederico. Ciência(s) da(s) Religião(ões). In: JUNQUEIRA, Sérgio; BRANDENBURG, Laude; KLEIN, Remí (Orgs.). Compêndio do Ensino Religioso. São Leopoldo: Sinodal; Petrópolis, RJ: Vozes, 2017. p. 131-138.

. Problematizando o conceito de religião. In: SILVEIRA, Emerson; COSTA, Waldney (Orgs.). A polissemia do sagrado: os desafios da pesquisa sobre religião no Brasil. São Paulo: Fonte Editorial, 2015a. p. 31-53.

. Religião e cinema. São Paulo: Fonte Editorial, 2015 b.

PISSOLATO, Elizabeth. "Tradições indígenas" nos censos brasileiros. In: TEIXEIXA, Faustino; MENEZES, Renata (Orgs.). Religiões em movimento: o Censo de 2010. Petrópolis, RJ: Vozes, 2013. p. 235-252. 
RODRIGUES, Elisa. O que é isso que chamamos Fenomenologia da religião? Reflexões em curso. In: SILVEIRA, Emerson; COSTA, Waldney (Orgs.). A polissemia do sagrado: os desafios da pesquisa sobre religião no Brasil. São Paulo: Fonte Editorial, 2015. p. 105-120.

. Ensino religioso, tolerância e cidadania na escola pública. Numen, Juiz de Fora, v. 16, n. 1, p. 211-229, jan./jun. 2013.

SCHLEIERMACHER, Friedrich. Sobre la religión: discursos a sus menospreciadores cultivados. Madrid: Editorial Tecnos, 1990.

SILVEIRA, Emerson; AVELLAR, Valter (Orgs.). Espiritualidade e sagrado no mundo cibernético: questões de método e vivências em Ciências da Religião. São Paulo: Edições Loyola, 2014. p. 15-48

; COSTA, Waldney (Orgs.). A polissemia do sagrado: os desafios da pesquisa sobre religião no Brasil. São Paulo: Fonte Editorial, 2015.

; MORAES JÚNIOR, Manoel. A dimensão teórica dos estudos de religião: horizontes histórico, epistemológico e metodológico nas Ciências da Religião. São Paulo: Fonte Editorial, 2017.

STIGGER, Marco Paulo. Esporte, lazer e estilos de vida: um estudo etnográfico. Campinas: Autores Associados, 2002.

TEIXEIXA, Faustino. A(s) Ciência(s) da Religião no Brasil: afirmação de uma área acadêmica. São Paulo: Paulinas, 2001.

WACH, Joachim. Sociologia da Religião. São Paulo: Paulinas, 1990.

WIRTH, Lauri. Religião e epistemologias pós-coloniais. In: PASSOS, João Décio; USARSKI, Frank (Orgs.). Compêndio de Ciência da Religião. São Paulo: Paulus/Paulinas, 2013. v. 1, p. 129-142.

YOUNG, Michael. Pra que servem as escolas?. Educação e Sociedade, Campinas (SP), v. 28, n. 101, p. 1287-1302, set./dez. 2007. 